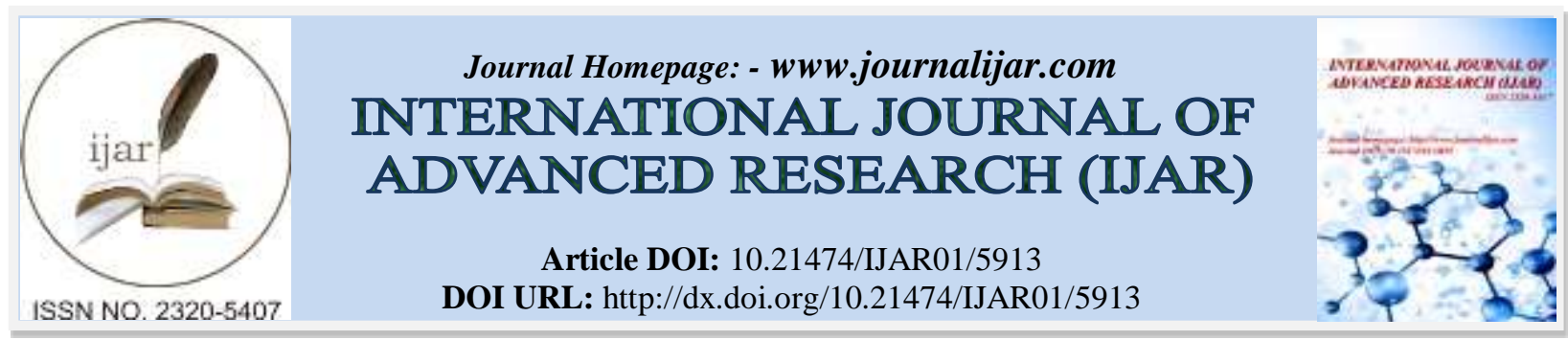

RESEARCH ARTICLE

\title{
EFFECT OF BUDGETARY PARTICIPATION AND MANAGERIAL ROLE OF LOCAL FINANCE ORGANIZER ON ORGANIZATIONAL PERFORMANCE EMPIRICAL STUDY AT GENERAL HOSPITAL DISTRICT OF MALANG REGENCY.
}

Suyitno.

Dosen STIE Indonesia Malang.

\section{Manuscript Info}

Manuscript History

Final Accepted: 21 October 2017

Published: November 2017

Key words:-

Budgetary Participation, Managerial

Role Of Local Finance Organizers And

Local Government Performance.
Received: 19 September 2017

\begin{abstract}
This research accounts for the effect of budgetary participation and managerial role of local finance organizer on local organization performance at General Hospital District of Malang Regency. The hypothesis of this research is that whether budgetary participation and the managerial role of the local finance organizer positively affect on the local government performance. The number of respondents as the research samples is 76 selected by using random sampling methods. The data collected by distributing questioners, there were 76 respondents giving back and only 76 questioners that could be processed and analyzed. The result of the research shows that budgetary participation and managerial role of local finance organizers affect positively significant on the organizational performance. The result of this research supports the previous researches and it is based on agency theory and prospect theory.
\end{abstract}

Copy Right, IJAR, 2017,. All rights reserved.

\section{Introduction:-}

Good Governance is the most prominent issue in the management of public administration today. The intense demands made by the community to the government for good governance in line with the increase of public knowledge and the influence of globalization demands openness. In order to realize good governance, the government continues to make various efforts by improving transparency and accountability of state financial management, one of them by perfecting the system of state administration as a whole. local governments need professional human resources (having high quality and competence), especially for those who sit in position, as emphasized in pasal 17 ayat (2) UU RI Nomor 43 Tahun 1999, namely the appointment of Civil Servants in a position implemented based on the principle of professionalism in accordance with competence, work performance and rank level assigned to the position. Merit increase of the salary and performance bonus are mostly determined by the combination of competence and performance apphraishal results (

Performance apparatus can be known success or failure in the performance, by determining the performance indicators, determining the results of performance indicators and factors that encourage in improving employee performance. The performance of the apparatus is judged by the behavior of its members in trying to show the best service to the public by utilizing the resources in the organization in providing satisfaction to the community as the party served (10). 
In terms of local financial management, local governments set goals and objectives and then create activity plans to achieve these goals and objectives. Achieving the goals of a local government requires the role of all members in the government. In order for government goals to be easy to achieve, a guideline called the budget is needed. A budget is a very important requirement. The budget is planned and prepared to serve as a guideline for all activities to be implemented. The budget is a tool of coordination of all activities to be implemented. Budgets are also used as standards or benchmarks that will be compared with actual results achieved from the execution of activities. The results of this comparison will be used to assess whether the activity has been running effectively and efficiently.

The budgets that have been set for implementation by existing units within the local government will in itself interact with the individuals in the government. The roles and interests of individuals in local government organizations to achieve local government objectives are based on individual interests to meet their goals or interests. But often the goals set by the local government conflict with individual goals resulting in low or inappropriate individual performance. The performance of each individual will affect the overall performance of government.

The budgeting process is an important activity and involves various parties. Budgeting is basically the process of determining the role of the head of the work unit in implementing the program unit or part of the program. Budgeting requires the cooperation of heads of work units within government organizations. The organizational structure of the work unit shows the responsibilities of each budget executive. Each implementer is responsible for preparing and managing the elements of their respective budgets.

In order for the implementation to be effective, the implementers participate in planning the budget, ie the extent of participation or participation in budget preparation. Participation in budgeting is assessed to improve the managerial performance of heads of work units that ultimately improve overall government performance. Subordinates who feel their aspirations are respected and have an impact on the budget set will have more responsibility and moral consequences to improve performance as targeted in the budget. However, in order to realize the performance of the government as a whole does not stop in the early stages of budgeting, but it takes the managerial role of regional leaders, especially financial managers in the region. The managerial role according to consists of individual roles, information roles and decision-making roles (16).

Research on budgeting in private sector organizations purely business or profit oriented (pure profit organization) has indeed been done. However, the results of research on purely profit-seeking organizations can not all be treated equally in public sector organizations. This is because there is a fundamental difference between the two. The difference is that in public sector organizations are not profit-oriented. Several public sector budget researches have been conducted, among others, using an ethnomethodological approach in the study of budget behavior. Ethnometodology is a collection of knowledge based on common sense and a set of procedures and considerations (methods) that ordinary people can understand, find out, and act on situations where they find identity $(\mathbf{8})$.

The researches on participation in budgeting that have been largely undertaken investigate the effect on managerial performance. While in this research will examine the effect on organizational performance on local government. Based on the above description, it is interesting to note is the performance achievement of the General Hospital of Malang Regency is on performance performance of a larger institution when compared with the realization of the shopping. General Hospital of Malang Regencywas chosen as a study with consideration of the performance of institution performance as a whole higher when compared with the realization of the shopping.

Whether this is due to the influence of participation in budgeting and managerial roles of local financial managers.Based on the reasons above this study wanted to test about the influence of participation in budgeting and managerial roles of local financial managers on the performance of local governments by taking the location of research at the General Hospital of Malang Regency.

\section{Formulation of the problem:-}

The formulation of the problem in this research is expressed in the form of question as follows:

1. Does participation in budgeting significantly affect the performance of the organization of General Hospital District of Malang Regency?

2. Is the managerial role of financial manager having a significant effect on the performance of the organization of General Hospital District of Malang Regency? 
3. Is participation in budgeting and managerial roles of financial managers simultaneously have a significant effect on organizational performance of General Hospital District of Malang Regency?

\section{Theoretical Basis:-}

\section{Participation in Budgeting:-}

Participation in budgeting is a process of individual participation to be evaluated, and may be rewarded on the basis of their achievement on the target (budgeted targets where they are involved in the process and have an impact on the targeting)(5). Understanding participation in budgeting in more detail is:

1. How far the budget is affected by the involvement of managers.

2. The reasons of the bosses at the time of the budget in the revision process

3. Frequency states initiative, give proposal and or opinion about budget to superiors without requested

4. How far managers feel has influence in the final budget

5. The interests of managers in their contribution to the budget

6. The frequency of budgets is discussed by the bosses at the time the budget is drawn up.

The conclusion to that the main factor that differentiates between the participation of budgeting and nonparticipation is the level of involvement and influence of subordinates to decision-making in the budgeting process. The process of organizing an organization's budget is a very important and complex activity, because the budget has the possibility of functional and dysfunctional impact on the attitudes and behavior of members of the organization (12).

Functional and dysfunctional impacts are indicated by the functioning of the budget as a good control tool to motivate members of the organization to improve their performance. Many factors cause budget dysfunctional, including performance criteria. To overcome the dysfunctional impact, Argyris (1952) suggests the need for subordinates to be given the opportunity to participate in the budgeting process. The target company wants will be more acceptable, if members of the organization can work together in a group to discuss their opinions on the company's goals, and be involved in determining the steps to achieve those goals(4).

Participation of managers in budget formation will lead to their initiatives to contribute ideas and information, increase togetherness and belonging, so that cooperation among members in achieving the goals also increases. Thus participation in budgeting is an effective way to create harmony and purpose of each responsibility center with the company's goals with the overall corporate objectives.However, under ideal conditions even participation in budgeting has limitations. Participation will allow for dysfunctional behavior, such as creating a budget slack. If a subordinate feels that their performance will be assessed on the basis of the level of budget achievement, they will not provide all the information they have at the time of budgeting. Another problem in participation is the occurrence of pseudoparticipation, a company claims to use participation in budgeting when it is not actually (15).

\section{Managerial Roles of Regional Finance Managers:-}

Based on Prospect Theory, it can be said that the Regional Finance Manager (PKD) will play an active role in every government policy when it feels that the implementation of the policy is profitable. On the contrary it will show a lack of support or lack of role and even refuse to any policy implementation when it feels that the policy is considered harmful. This attitude will affect the overall performance of the organization (9). Performance-oriented financial management demands decentralization. Decentralization of local financial management is an administrative decentralization, namely the delegation of implementation authority to the lowest level of hierarchy. In this case the Regional Finance Manager is authorized within the limits set forth in the regional financial management system, but they have certain elements of policy and power and responsibilities in terms of the nature and nature of the services and services it is responsible for (6). The manager is the person responsible for the organization or unit he leads. The manager's job can be described in terms of various "roles" or set of organized behaviors identified by a position (13), (17). Mitzberg explains that managers can play three roles through their authority and status in performing the tasks entrusted, among others:

1. Interpersonal roles. In this case a manager must be able to play the role of forehead, leader and liaison (liaison)

2. Informational Roles. In this case a manager must be able to play his role as a monitor, an informer and as a spokesperson

3. The role of decision makers. In this role, managers are described as entrepreneurs, disturbance handles, resource allocators and negotiators. 
The description of the role of managers mentioned above will require a number of important managerial skills, develop equal working relationships, negotiate, motivate subordinates, resolve conflicts, build information networks and pay for information, make decisions under extreme ambiguity conditions, and allocate existing resources. Besides, a manager needs to instrospect about the task and its role so as to achieve maximum performance.

The managerial role of Regional Finance Manager enables the achievement of efficient and effective governance performance and mechanism. Role shows a person's participation in realizing organizational goals. The managerial role of Regional Finance Manager demonstrates the achievement of efficient and effective governance mechanisms. Decentralization provides an opportunity for Regional Finance Managers to encourage the creativity of Regional Finance Managers. Individuals involved and given responsibility in budgeting will work harder to achieve the goals, so that organizational performance will be higher (14).

\section{Bureaucratic Organization Performance:-}

Improved budget performance and local financial management occupy an important position in the Local Government's empowerment strategy for the implementation of regional autonomy and realizing broad, tangible and responsible decentralization. Performance-oriented spending planning will improve the performance of local budgets.

Performance can be explained as a study of the ability of an organization in achieving goals. Performance appraisal can be used to measure organizational activities in achieving goals as well as materials for future improvement (3). From the opinion can be said that the performance of the organization is an achievement of work and organizing process for the achievement of organizational goals that have been set. Estimated amount of fund allocation for each work unit of local government and work program needed to produce a level of public service, adapted to the demands and needs of the community, so that input identification, public service production techniques and the minimum level of quality that must be produced by a work unit becomes a condition in determining the optimal allocation of funds for each unit of public service work (2). Thus the expenditure of Local Government can create performance measures that will facilitate in conducting activities of control and evaluation of local government policy. Because it is the policy of Local Government, the orientation of Local Government on development will be closer to the dynamic movement of its people. This means that it will be open so that public demands and needs are included in the determination of strategy, priorities and allocation policies.

The regional budget is a technical design for the implementation of the strategy, so that if government spending has a low quality, then the quality of the implementation of the functions of the Regional Government also tends to weaken which results in the form of regional and local government in the future is difficult to achieve.

In order to improve the performance of local budgets, one important aspect is the issue of local financial management and local budgets. Therefore, it is necessary for the regional financial management to control the regional financial policy economically, efficiently and effectively (11). The role of Regional Government is no longer a tool of interest of the Central Government, but a tool to fight for the aspirations and interests of the region. The Value For Money (VFM) concept is important for the Local Government as a public servant, as its implementation will provide benefits such as:

1. Effectiveness of public services, in the sense that the services provided are right on target;

2. Improving the quality of public services;

3. Low cost of service, due to loss of inefficiency and savings in the use of resources;

4. Public expenditure-oriented spending;

5. Increasing public cost awareness as the root of the implementation of public accountability.

In the context of regional autonomy, VFM is a bridge to deliver Local Governments to achieve good governance, namely transparent, economical, efficient, effective, responsive and accountable. The VFM should be operationalized in local financial management and local budgets(11). Measures in VFM measurement of regional expenditure can be detailed according to the following indicators:

\section{Economic measurement:-}

Economics is related to the conversion of primary inputs in the form of financial resources (money / cash) into secondary inputs in the form of labor, materials, infrastructure, and capital goods consumed for the activities of the 
organization. The organization shall ensure that in the acquisition of input resources, such as materials, goods, and raw materials there is no waste.

\section{Efficiencymeasurement:-}

Efficiency can be measured by the ratio between output / output and secondary input / input (expenditure). The greater the output produced compared to the expenses made, the more efficient an organization. The efficiency ratio is not expressed in absolute form but in relative form. Because the efficiency is measured by comparison of output and input.

\section{Effectivenessmeasurement:-}

Effectiveness is a measure of success or failure of the achievement of an organization's goals. When an organization succeeds in achieving its objectives then the organization has run effectively. The most important thing to note is that effectiveness does not state how much expenditure has been spent to achieve that goal. Spending may exceed what has been budgeted. Effectiveness is the ratio between outcome and output (output).

According to Robbins, performance is a work behavior that is expressed by people seen in a company and can be explained through a performance evaluation system. Company performance is an achievement level indicator that can be achieved and reflects the success of managers. So the company's performance is the desired result of the company from the behavior of the people inside (16).

Conceptual framework in this research can be described as follows:

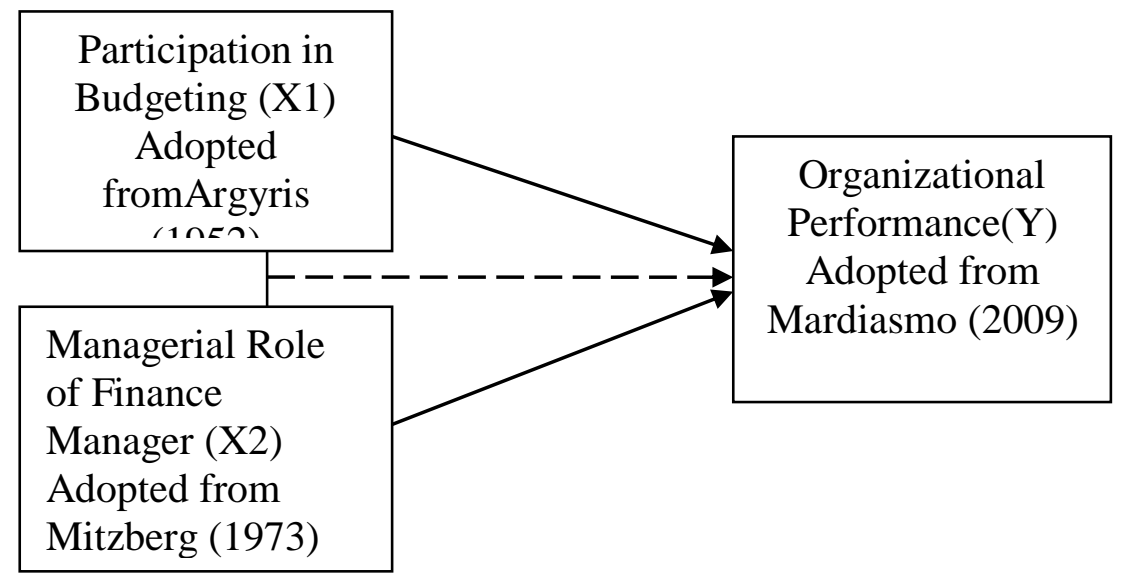

Figure 2:- Conceptual framework of research

\section{Research Methods:-}

This study examines and discusses the influence of participation in budgeting and managerial role of Finance Manager on organizational performance of General Hospital District of Malang Regency by using non experimental quantitative research design. Data collected through questionnaires distributed to 76 respondents and supported by interview and observation techniques, then the data collected and then analyzed both in descriptive statistics and inferential statistics with the help of SPSS program version 17.

\section{Research Results and Discussion:-}

Regression Analysis:-

Analysis of hypothesis testing of this study using multiple regression. This test is used to examine the effect of participation in budgeting and managerial role of financial manager on organizational performance in General Hospital District of Malang Regency.

Table 1:-Summary of Multiple Liniear Regression

\begin{tabular}{|c|c|c|c|c|}
\hline Variable & Coef. Regresion & Std. error & T. Stat & Sign \\
\hline $\mathrm{X} 1$ & ,475 & ,425 & 2,283 & ,013 \\
\hline $\mathrm{X} 2$ &, 512 & ,454 & 3,098 & ,004 \\
\hline
\end{tabular}




\begin{tabular}{|c|c|c|c|c|}
\hline Constant & 2,754 & 2.457 & 2,644 & ,419 \\
\hline Multiple R & & & \multicolumn{2}{|c|}{0,623} \\
\hline $\mathrm{R}$ square & & & \multicolumn{2}{|c|}{0,653} \\
\hline Adjusted R. Square & & & \multicolumn{2}{|c|}{0,527} \\
\hline Standart Error & & & \multicolumn{2}{|c|}{34,541} \\
\hline F. Ratio & & & \multicolumn{2}{|c|}{23.112} \\
\hline Durbin Watson Test & & & \multicolumn{2}{|c|}{2.4245} \\
\hline F sign & & & \multicolumn{2}{|c|}{0,010} \\
\hline
\end{tabular}

Dependent Varieable: Y

Based on table 1 above that can be interpreted that the organization's performance General Hospital of Malang Regencyvariable is influenced by the variable participation in budgeting and managerial role of financial manager, with the following equation:

$$
Y=2,754+0,475 X 1+0,512 X 2+0,425
$$

In the multiple linear regression formulation above obtained by the constant value of 2.754 has the understanding that if the score of participation in budgeting (X.1), Managerial Role of Finance Manager (X.2) zero value means the condition of organizational performance inGeneral Hospital of Malang Regency variable is in score 2.754 .

The value of regression coefficient of variable participation in budgeting (X.1) of 0.475 means there is a positive influence of participation variable in budgeting on organizational performance in General Hospital of Malang Regencyamounted to 0.475 so that if the score of participation variables in budgeting rose 1 point, it will be followed by a score increase the organization's performance inGeneral Hospital of Malang Regencyis $0,0,475$ points.

The value of variable regression coefficient The managerial manager role of Finance (X.2) of 0.512 means there is a positive influence variable Managerial Manager of Finance to the performance of the organization in General Hospital of Malang Regencyamounted to 0.512 so that if the variable score managerial manager managerial roles rose 1 point, it will be followed with the increase of organizational performance score inGeneral Hospital of Malang Regencyequal to 0,512 points.

Based on the results of determination test can be seen that the magnitude of R Square value of 0.653 which means variability of organizational performance variable in General Hospital of Malang Regency can be explained by the variability of participation in budgeting and managerial managerial roles of $65.3 \%$. While the remaining $34.7 \%$ is explained by other variables not included in this study.

\section{Hypothesis Testing 1:-}

Hypothesis 1 states that there is a positive influence and significant participation in budgeting on the organization's performance General Hospital of Malang Regency. In table 1, it can be seen the value of $\mathrm{t}$ arithmetic 2,283 while the value of $\mathrm{t}$ table at the level of significance $5 \%$ and $\mathrm{df}==(76-2-1)=73$ of 1.99 (can be seen in table $t$ distribution) so $\mathrm{t}$ stat> $\mathrm{t}$ table $(2.283>1.99)$. If $\mathrm{t}$ stat $>\mathrm{t}$ table then the analysis results are stated significant. It can be concluded that hypothesis 1 is that participation in budgeting has a positive and significant effect on organization performance of General Hospital of Malang Regencyaccepted.

From the results of testing the first hypothesis states that participation in budgeting has a positive and significant impact on the performance of local governments. Mid and low-level managers (users and power users / budget users) at the General Hospital of Malang Regency are involved or participating in budget preparation, because with participation in budgeting, they are given the opportunity to play a role in providing inputs and ideas they are poured in the form of a budget that they will carry out. Users and the power user / goods authority at the General Hospital of Malang Regencyfeel more comfortable working on their own budget basis than the budget set by their supervisor and they feel responsible for what has been set in their budget. In addition, the application of participation also allows the users and the power user / budget authority at the General Hospital of Malang Regencyto encourage supervisors by providing their information so that the budget is made more accurate because the subordinates have specific information about local conditions and will report the condition to superiors. 


\section{Hypothesis Testing 2:-}

Hypothesis 2 states that there is a positive and significant influence of the managerial role of financial managers on the organization's performance General Hospital of Malang Regency. Table 1 shows the value of $t$ arithmetic of 3.098 while the $t$ value of the table at the 5\% significance level and $\mathrm{df}=(76-2-1)=73$ of 1.99 (can be seen in the $t$ distribution table) so $t$ stat $>t$ table (3.098> 1.99). If $t$ stat $>t$ table then the analysis results are stated significant. It can be concluded that hypothesis 2 is the managerial role of financial manager has a positive and significant effect on the organization's performance General Hospital of Malang Regency accepted.

Results of testing the second hypothesis states that the managerial role of financialmanagers have a positive and significant impact on organizational performance General Hospital of Malang Regency. This indicates that there is a role performed by the local financial management officials (users and power users/budgetors) to encourage and motivate their subordinates to achieve the organization objectives of General Hospital of Malang Regency. The managerial roles of local financial managers such as interpersonal roles, information roles and decision-making roles affect the organization's performance. With the managerial role, encourage the local financial managers to better participate in achieving better organization performance General Hospital of Malang Regency, implement the goals set by the organization's performance General Hospital of Malang Regency.

The users and the power user / goods authority at the General Hospital of Malang Regencyfeel responsible and feel the control of what has been established General Hospital of Malang Regency. The existence of this managerial role also encourages local financial managers to have a high commitment to achieve local government performance. This high commitment to financial management has a positive perspective and tries to do the best to achieve better goals and performance.

\section{Hypothesis Testing 3:-}

Hypothesis 3 states that there is a positive influence and significant participation in budgeting and managerial roles of financial managers simultaneously on the organization's performance of General Hospital of Malang Regency. Table 1 shows the Fstat value of 12.112 while the $\mathrm{F}$ table at the 5\% significance level and df1 $=\mathrm{k}-1=3-1=2$ and $\mathrm{df} 2=\mathrm{n}-2=76-2=74$, of 3.12 (can be seen in table $\mathrm{F}$ distribution) so that $\mathrm{F}$ stat $>\mathrm{F}$ table (12.112> 3.12). If $\mathrm{F}$ stat $>\mathrm{F}$ table then the analysis results are stated significant. It can be concluded that hypothesis 3 is participation in budgeting and managerial role of financial manager simultaneously have a positive and significant effect on organization performance of General Hospital of Malang Regencyaccepted.

Summary of contribution and interrelation among variables in this study are shown in Figure 3.

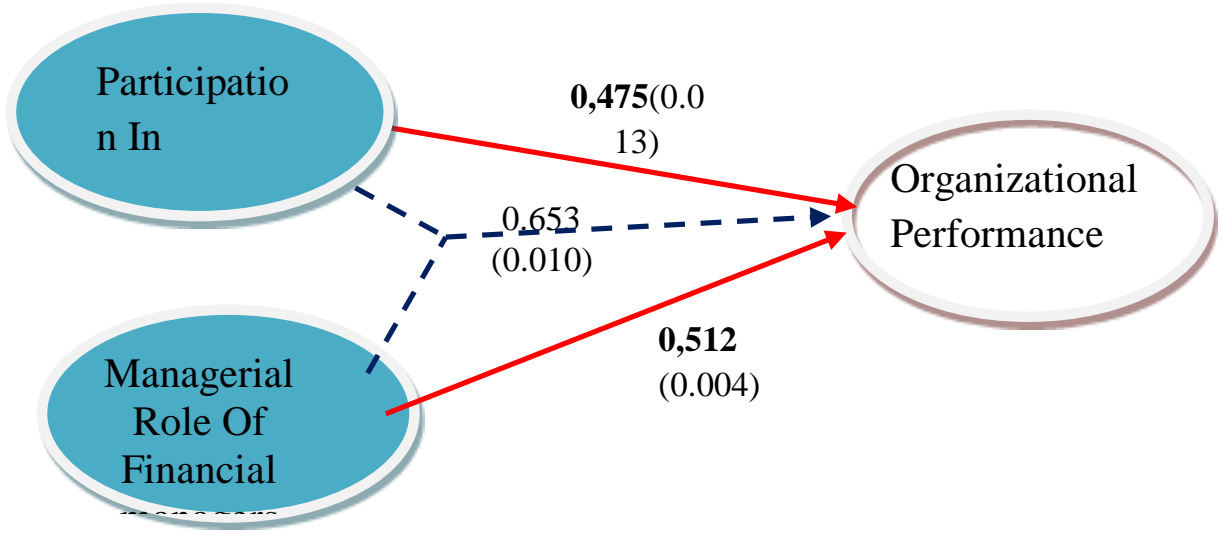

Figure 3:- Relation of Inter-variables

\section{Conclusions:-}

Based on the results of testing and data analysis in this study it can be obtained conclusion as follows:

1. There is a significant positive effect of participation in budgeting on organizational performance General Hospital of Malang Regency. The higher the participation in budgeting, it will further improve the organization performance of General Hospital of Malang Regency. This is supported by a regression coefficient of 0.475 at a 0.013 significance level. 
2. There is a significant positive influence of the managerial role of financial managers on the organization's performance General Hospital of Malang Regency. The higher the managerial role of financial managers will increasingly improve the performance of hospitals General Hospital of Malang Regency. This is supported by a regression coefficient of 0.512 at a significance level of 0.004 .

3. There is a significant positive effect of participation in budgeting and managerial roles of financial managers simultaneously on the organizationperformance General Hospital of Malang Regency. The higher the managerial role of financial managers will increasingly improve the organization performance of General Hospital of Malang Regency. It is supported by Fstat value 23.112 bigger than F table 6.99 and significance level of 0.010 .

\section{Reference:-}

1. Argyris, C.1952. The Impact of Budget on People, Ithaca, NY : The Controllership Foundation, Inc. Cornell University

2. Asmoko, Hindri, 2006, Pengaruh Penganggaran Berbasis Kinerjaterhadap Efektifitas Pengendalian, JurnalAkuntansiPemerintah Vol. 2, No. 2, Hal 53 - 64

3. Becker, Brian AndGerhart, Barry, 1996. The Impact Of Human ResourceManagement On Organization Performance : Progress And Prospect, Academy of Management Journal, Vol. 39 (4)

4. Brownell, Peter, 1982, The Role of Accounting Data in Performance Evaluation, Budgetary Participation, and Organizational Effectiveness, Journal of Accounting Research, Vol 20, pp 12-27

5. Brownell, Peter and Mc. Innes Morris, 1986, Budgetary Participation Motivation and Manajerial Performance, The Accounting Review

6. Coralie, Byant and White Louise, 1987, Manajemen Pembangunan untuk Negara Berkembang, Terjemahan, LP3ES

7. Dunk, A.S dan AF Lysons, 1997, An Analysis of Departemental Effectiveness Participative Budgettaty Control Process and Environmental Dimensionality within The Competing Values Framework : A Public Sector Study, Financial, Accountability and Manajemen, Volume 13 No 1 pp 1-15

8. Johnson, 1982, Budgetary Behavior in Local Government A Case Study over 3 years, Accounting, Organization and Society, $7: 287-304$

9. Kahnerman, D and A Tversky, 1979, Prospect Theory: an Analysis of Decisions under Risk, Econometrica47 : p 263-291

10. Mahsun, M. 2006. PengukuranKinerjaSektorPublik.Yogyakarta:BPFE-UGM

11. Mardiasmo (2009). AkuntansiSektorPublik. Yogyakarta: Andi

12. Milani, K, 1975, The Relationship of Participation in Budget-setting of Industrial Supervisor Performance and Attitudes : a Field Study, The Accounting review 50

13. Mitzberg, H, 1973, The Nature of Manajement Work, Harper Row

14. Rohman, Abdul, 2007, PengaruhPeranManajerialPengelolaKeuangan Daerah danFungsiPemeriksaan Intern terhadapKinerjaPemerintah Daerah (Survey padaPemda Kota, KabupatendanProvinsi di Jawa Tengah), JurnalMaksi, Vol 7 No 2 Agustus 2007, hal 206-220

15. Siegel, G and HR Marcony, 1989, Behavioral Accounting, South Western Publishing Co. Cincinnati, OH

16. Supriyono, 2015, Profesionalisasi Guru Bahasa Inggris Sekolah Menengah Yayasan Pendidikan Jayawijaya Menuju Sekolah Bertaraf Internasional:Sebuah Analisis Reflektif Dalam Perspekti Psikologi, KONSTRUKTIVISME, Vol. 7, No. 1, Januari 2015, p-ISSN: 1979-9438, e-ISSN: 2445-2355, FKIP Universitas Islam Balitar, Blitar, http://unisbablitar.ejournal. M web.id/index.php/konstruktivisme/article/view/21/21

17. Suyitno, 2016.The Enhancement Of Human Resources Through The Implementation Of Total Quality Management At Pr Prima In Malang, East Java-Indonesia, Journal of Social Sciences (COES\&RJ-JSS). Vol 5 No 4.page 557-565. http://doi.ogr/10.25255/jss.2016.5.4.557.565.

18. Suyitno, 2017. Effect of Competence, Satisfaction and Discipline on Performance of Employees in the Office of Women Empowerment and Family Planning of West Papua, Asian Social Science, Vo 13 No 5. DOI: https://doi.org/10.5539/ass.v13n5p144. 